\title{
Biographies of Contributors / Notices biographiques
}

Ottilia Chareka is a PhD candidate in Education at the University of New Brunswick and a sessional instructor in social studies methods at the School of Education, St. Francis Xavier University, Antigonish, Nova Scotia, specializing in Citizenship Education and Global Education. Born in Bikita, Zimbabwe, she trained as a teacher and obtained a Certificate in Theory of Education from the University of Zimbabwe. She came to Canada in 1990 and completed her DAUS and MEd at the University of New Brunswick in the area of Global Education. Her research interests are in citizenship, human rights, global and multicultural education, and international migration, in particular integration of immigrants.

Glen Eyford is professor emeritus, Faculty of Education, University of Alberta. His teaching and research interests include comparative international development, cross-cultural learning, media and education, aesthetics and education. He served two terms on the board of the UNESCO Institute for Education in Hamburg, and was board member for seven years of the Landegg International University in Switzerland. He has published extensively in the fields of arts in education and community development.

Professor at the University of Calgary, Yvonne Hébert specializes in values and citizenship education, identity formation, social capital, minority education, language and cultural studies. Founding coordinator of the Citizenship Education Research Network, she now serves as past president. She is the editor of Citizenship in Transformation in Canada (Université d' Toronto Press, 2002) and co-editor of Negotiating Transcultural Lives: Belongings and Social Capital among Youth in Comparative Perspective, with Dirk Hoerder and Irina Schmitt (2005, V\&Runipress, Göttingen).

R. Brian Howe is a professor of political science and co-director of the Children's Rights Centre at the University College of Cape Breton. He is the coauthor of Empowering Children (2005) and The Challenge of Children's Rights for Canada (2001); and author of numerous articles on human rights and children's rights.

France Jutras est professeure titulaire en Fondements de l'éducation à l'Université de Sherbrooke. Ses travaux portent spécifiquement sur les valeurs de l'éducation et l'éthique professionnelle en éducation. C'est ce qui l'a menée à l'éducation à la citoyenneté sous l'angle du développement de la personne comme être social. Elle est actuellement présidente du Réseau de recherche en éducation à la citoyenneté / Citizenship Education Research Network.

Stéphane Lévesque est professeur adjoint à la Faculté d'Éducation, University of Western Ontario oú il enseigne la didactique de l'histoire et l'éducation civique au secondaire. Ses recherches portent sur les conceptions historiques des jeunes francophones et anglophones. Il est membre du conseil d'administration de la 
Fondation Historica et auteur du volume Thinking Historically: Educating Citizens for the 21st Century, à paraître aux Presses de l'Université de Toronto.

Camerounais, Charles-Romain Mbele a étudié la philosophie à l'Université de Yaoundé jusqu'au DEA et a été chercheur en pensée africaine. Après une thèse de Doctorat Nouveau régime à l'Université de Paris I-Panthéon-Sorbonne, il enseigne la philosophie à l'École Normale Supérieure de l'Université de Yaoundé I. Membre fondateur du Club de philosophie Kwamé Nkrumah qui publie la revue Zeén dont il est rédacteur, il anime une émission radiophonique hebdomadaire de philosophie en langue beti. Il est membre de l'Association de recherche interculturelle (ARIC).

Jan Pouwels is a philosopher of education at the University of Professional Education of Arnhem and Nigmegen (HAN) in the Netherlands, where he serves as co-ordinator of International Relations. He is co-editor of Human Rights and Values Education in Europe: Research in Educational Law, Curricula and Textbooks, How to be a Teacher in a Europe of Human Rights, and The Europe of Human Rights.

Alan Sears is professor of social studies education at the University of New Brunswick. He has written extensively about social education in general and citizenship education in particular. He is co-editor of Challenges and Prospects in Canadian Social Studies and Chief Regional Editor for Canada for the International Journal of Citizenship and Teacher Education.

Lori Wilkinson is an Assistant Professor in the Department of Sociology at the University of Manitoba. She is actively involved in research on the life course transitions of immigrant and refugee youth, the health and well-being of immigrant children, and the social capital and identity formation of young adults.

伍 洲 Joe Zhou Wu is an associate professor in the Faculty of Education, the University of Alberta, specializing in Second Language Education. Born in Harbin, China, he came to Canada in 1987 and completed his Ph.D. at Université d' of A. His research interests are in language, culture, ethnic identity, bilingual and multicultural education. 


\section{Coordonnées/Contributors’ Contacts}

Ottilia Chareka

School of Education

St. Francis Xavier University

Antigonish, Nova Scotia

E: ochareka@stfx.ca

Glen Eyford

Professor Emeritus

Faculty of Education

University of Alberta

Mailing address: 46 Riverview Circle

Cochrane, AB T4C $1 \mathrm{~K} 3$

T: 403.932.6679

E: GlenEyford@shaw.net

Yvonne Hébert

Faculty of Education

University of Calgary

2500 University Drive NW

Calgary $A B$ T2N $1 N 4$

T: 403.220 .7361

F: 403.282.8479

E:yvonne.hebert@ucalgary.ca

Lori A. Wilkinson

Department of Sociology

318 Isbister Building

Winnipeg, $M B$

CANADA R3T 2N2

Phone: 204-474-8491

Fax: 204-261-1216E:

LoriWilkinson@umanitoba.ca

Home: 635 Munroe Avenue

Winnipeg, $M B$

CANADA R2K 1 H9

Phone: (204) 654-4577

Cell: (204) 998-4577

\section{Joe Zhou Wu}

Department of Elementary Education

Faculty of Education

University of Alberta

551 Education South

Edmonton, AB T6G 2 G5

Phone: (780) 492-5417

Fax: (780) 492-7622

Email:jwu@ualberta.ca
Jan G. Pouwels

University of Professional Education of

Arnhem and Nijmegen (HAN)

Faculty of Education

Department Primary "Pabo Groenewoud"

Groenewoudseweg 1

6524 TM Nijmegen

The Netherlands

Tel. 024-3233778/ direct 3823820

Fax. 024-3603402

E-mail: jan.pouwels@han.nl (work)

Website: www.han.nl

E-mail:jg.pouwels@home.nl (private)

Alan Sears

Faculty of Education

University of New Brunswick

P. O. Box 4400

Fredericton, NB E3B 5 A3

T: 506-453-5178

F: 506-453-3569

E: asears@unb.ca

R. Brian Howe

Political Science

Director, Children's Rights Centre

University College of Cape Breton

Sydney, NS, Canada B1P $6 L 2$

T: 902-563-1214

$F: 902-562-0119$

E: Brian_Howe@uccb.ca

France Jutras

Faculté d'éducation

Université de Sherbrooke

Sherbrooke, Qc J1K 2R1

Téléphone : (819) 821-8000 poste 1901

Télécopieur : (819) 821-6944

Adresse de courriel :

France.Jutras@USherbrooke.ca

Charles Romain Mbele

Département de Philosophie et

d'Anthropologie

École Normale Supérieure

Université de Yaoundé I

BP 7840 Yaoundé

Cameroun

romain.mbele@laposte.net

92 Canadian and International Education Vol. 34 no. 1 - June 2005 


\section{Appendix}

\section{From the: Universal Declaration of Human Rights (1948)}

Article 26.

1. Everyone has the right to education. Education shall be free, at least in the elementary and fundamental stages. Elementary education shall be compulsory. Technical and professional education shall be made generally available and higher education shall be equally accessible to all on the basis of merit.

2. Education shall be directed to the fullest of the human personality and to the strengthening of respect for human rights and fundamental freedoms. It shall promote understanding, tolerance and friendship among all nations, racial and religious groups, and shall further the activities of the United Nations for the maintenance of peace.

3. Parents have a prior right to choose the kind of education that shall be given to their children.

http://www.unhchr.ch/udhr/index.htm

\section{From the: Convention on the Rights of the Child (1989)}

Article 28

1. States Parties recognize the right of the child to education, and with a view to achieving this right progressively and on the basis of equal opportunity, they shall, in particular:

(a) Make primary education compulsory and available free to all;

(b) Encourage the development of different forms of secondary education, including general and vocational education, make them available and accessible to every child, and take appropriate measures such as the introduction of free education and offering financial assistance in case of need;

(c) Make higher education accessible to all on the basis of capacity by every appropriate means;

(d) Make educational and vocational information and guidance available and accessible to all children;

(e) Take measures to encourage regular attendance at schools and the reduction of drop-out rates.

2. States Parties shall take all appropriate measures to ensure that school discipline is administered in a manner consistent with the child's human dignity and in conformity with the present Convention.

3. States Parties shall promote and encourage international cooperation in matters relating to education, in particular with a view to contributing to the elimination of ignorance and illiteracy throughout the world and facilitating access to scientific and technical knowledge and modern teaching methods. In 
this regard, particular account shall be taken of the needs of developing countries.

Article 29

1. States Parties agree that the education of the child shall be directed to:

(a) The development of the child's personality, talents and mental and physical abilities to their fullest potential;

(b) The development of respect for human rights and fundamental freedoms, and for the principles enshrined in the Charter of the United Nations;

(c) The development of respect for the child's parents, his or her own cultural identity, language and values, for the national values of the country in which the child is living, the country from which he or she may originate, and for civilizations different from his or her own;

(d) The preparation of the child for responsible life in a free society, in the spirit of understanding, peace, tolerance, equality of sexes, and friendship among all peoples, ethnic, national and religious groups and persons of indigenous origin; (e) The development of respect for the natural environment.

2. No part of the present article or article 28 shall be construed so as to interfere with the liberty of individuals and bodies to establish and direct educational institutions, subject always to the observance of the principle set forth in paragraph 1 of the present article and to the requirements that the education given in such institutions shall conform to such minimum standards as may be laid down by the State.

http://www.unicef.org/crc/crc.htm

http://www.unhchr.ch/html/menu3/b/k2crc.htm 